\title{
HALYCHYNA. JOURNAL OF REGIONAL STUDIES: SCIENCE, CULTURE, AND EDUCATION. TWENTY YEARS OF PUBLISHING ACTIVITY
}

\author{
MYKOLA KUHUTIAK, IHOR RAIKIVSKYI, OLEH YEHRESHII
}

\begin{abstract}
This is a review of the twenty-year-long publishing activity of Halychyna. Journal of Regional Studies: Science, Culture and Education, one of the first Ukrainian journals for historians, philologists, art critics that appeared in the independent Ukraine. In Halychyna, there has been published the works by well-known scholars of Vasyl Stefanyk Precarpathian National University and many other higher educational establishments of Ukraine. The Journal can boast an array of sections - archaeology, history, ethnology, political science, historiography, source studies, documents and materials, culturology, art criticism, historical biography studies, and others. Most of the studies published in Halychyna focus on the issues of the modern and contemporary history of Ukraine, ethnology. A special attention is given to the issues of the Ukrainian national liberation movement in the $20^{\text {th }}$ century, the Ukrainian national revival in the $19^{\text {th }}-20^{\text {th }}$ century, the activity of the political parties in Galicia in the late 19th-early $20^{\text {th }}$ century, source studies and historiography in Ukraine, historical regional studies, the problems of modern state formation in Ukraine, and others.
\end{abstract}

Keywords: Halychyna. Journal of Regional Studies: Science, Culture and Education, history, Vasyl Stefanyk Precarpathian National University, publishing activity.

Halychyna. Journal of Regional Studies: Science, Culture and Education has been published in IvanoFrankivsk since 1997. The Journal continues the tradition of research on the history of lands and regions of Ukraine started by prominent Ukrainian scholars Mykhailo Hrushevsky, Ivan Franko, Volodymyr Hnatiuk, Ivan Krypiakevych, and others. On the regional level, historical researches were conducted even in the Soviet times despite the hindrances set by the totalitarian Communist Party regime. For example, there were published a multivolume Istoriia mist $i$ sil Ukrainskoi RSR (A History of the Cities, Towns, and Villages of the Ukrainian SSR), the collection of papers Z istorii zakhidnoukrainskykh zemel (From the History of the Western Ukrainian Lands) and others. Yet, for ideological reasons, the regional studies of that period were one-sided, various aspects of the national history were distorted, certain facts were omitted. Oleksandr Dovzhenko rightly stated that the Soviet Ukraine was the only country in the world where the national history was not taught at the universities, where it was regarded as something prohibited, inimical, and counterrevolutionary ...' [1, p. 43] .

\footnotetext{
* All quotations are translated from the original Ukrainian texts.
} 
With the proclamation of the national and state independence in 1991, the ideological barriers were removed; now that researchers have access to archive sources, to the materials which represent achievements of Western and traditional Ukrainian historiography (they used to be classified as Top Secret), there is every possibility for carrying out objective, unbiased research. Knowledge of the national and cultural traditions of this or that region, a 'small' homeland, is the basis for the comprehension of the Ukrainian national idea, the developing of patriotism; without it, spiritual development and consolidation of the modern Ukrainian nation is impossible. According to Vyacheslav Lypynsky, a famous Ukrainian historian, 'territorial patriotism..., which results from the settlement instinct' is 'at the heart of the organization of any nation'. It shows the importance of regional history, certain aspects of the historical past of a land or region since they are prerequisite for true comprehension of Ukrainian national history - the understanding of the general comes through the knowledge of the particular.

Halychyna. Journal of Regional Studies: Science, Culture and Education was one of the first professional journals that appeared in the independent Ukraine; its target readers are historians, philologists, art critics, those interested in regional studies. In their foreword, the editors wrote, 'This new publication launched by a group of scholars of Ivano-Frankivsk, Lviv, Kyiv is caused by ... the need to objective and scientifically verified research into various aspects of the social life of our land [Galicia], its specific historical experience.' The editors of the newly created Journal aimed 'to carry out systemic research into the most important and the least studied issues of the regional and national history, cultural studies, political science, literary criticism, art criticism, ... the historical aspect of ethnopolitical relations in the land ..., the specific features of interconfessional relations'. It was also planned to publish authentic materials in the field of the history of Ukraine - 'documents, papers, reminiscences that shed light upon hitherto unstudied events in the regional history'; of special interest were the problems of modern state formation [2, p. 1].

The publication was initiated by Mykola Kuhutiak, Doctor of History, Professor, Honoured Worker of Science, the first and permanent Chief Editor of Halychyna. The Journal is the result of a purposeful twenty-year-long work of the researchers - the Professors and the teaching staff of the Institute of History, Political Science, and International Relations (before 2005, called the Faculty of History) of Vasyl Stefanyk Precarpathian National University.

In 1998, Halychyna was registered by the Resolution of the Higher Attestation Commission of Ukraine as a professional publication in the fields of history, philology, and art criticism; in 2010, it was re-registered as a professional publication in the fields of history and art criticism; in 2015, in the field of history.

According to the Certificate of State Registration of Print Media, the programme goals of the Journal are 'objective presentation of the historical past of the land, popularization of the cultural heritage of the Ukrainian people, analysis of the situation in the contemporary Ukraine'. The members of the Editorial Team are M. Kuhutiak (Chief Editor), I. Raikivskyi and O. Yehreshii (Executive Secretaries), O. Marushchenko, A. Korolko, L. Sholohon, H. Stefaniuk, M. Vitenko and some other persons. During different perriods, authoritative Ukrainian scholars V. Hrabovetsky, V. Greshchuk, V. Kachkan, V. Kononenko, V. Matviishyn, R. Chuhai, T. Salyha, M. Stankevych, and others were on the Editorial Board.

In Halychyna, there were published the works by well-known Ukrainian scholars of Vasyl Stefanyk Precarpathian National University and the Universities of Kyiv, Kharkiv, Donetsk, Kryvyi Rih, Sevastopil, Simferopol, Odesa, Chernihiv, Rivne, Zhytomyr, Vinnytsia, Mykolaiv, Lviv, Lutsk, Ternopil, Uzhhorod, Kamianets-Podilskyi, Bila Tserkva, Pereiaslav-Khmelnytskyi, Ostroh, Drohobych, Kremenets, and other cities. The artistic design of the Journal was made by well-known Precarpathian artists M. Hatalevych, M. Yasinskyi, I. Tokaruk, O. Chuiko, V. Khomyn, M. Korpaniuk.

Soon Halychyna will celebrate its $20^{\text {th }}$ anniversary. 27 issues have already been published, the $28^{\text {th }}$ one is forthcoming. The materials published in the Journal (about one thousand) trace the history of the land in the all-Ukrainian context, thus developing national identity, in university and high school students in particular. 
The materials were published in the Journal's sections on archaeology, history, ethnology, political science, historiography, source studies, documents and materials, culturology, art criticism, historical biography studies, historical regional studies, historical ethnodemography, museology, historical geography, monument studies, linguistics, education history, publicism, medium aevum, research debut, bibliography, reviews, science events, anniversaries, memori, and some others. In Halychyna, apart from the research papers of the Professors of the Institute of History, Political Science, and International Relations, there were published the works by the well-known scholars of Vasyl Stefanyk Precarpathian National University (Honored Artist of Ukraine, Professor M. Fihol; Professor S. Pushyk, a writer and poet; Professor V. Poliek; Professor S. Vozniak, and others) and other institutions of higher education. O. Reient, O. Lysenko, Yu. Shapoval, V. Serhiichuk, F. Pohrebennyk, V. Baran, D. Stepovyk, O. Udod (Kyiv); L. Zashkilniak, M. Lytvyn, S. Makarchuk, I. Pater, K. Kondratiuk (Lviv); V. Botushanskyi, P. Brytskyi, O. Dobrzhanskyi, H. Kozholianko (Chernivtsi) and many other famous scholars contributed to the Journal.

The papers by well-known scholars from Poland, the USA, Russia were published in Halychyna; for instance, those by Nathan D. Shippee, Professor, Doctor of Philology in Sociology (Indiana State University, USA); Leonid Rudnytzky, Professor, Dr. habil., Academician of the National Academy of Sciences of Ukraine (University of Pennsylvania, USA); Vjeslav Lukash Matsiezhynski, Professor, Dr. habil. (Faculty of Journalism and Political Science, University of Warsaw, Republic of Poland); Eugeniusz Koko, Professor, Dr. habil. (University of Gdańsk, Republic of Poland); Alexander Maiorov, Professor, Doctor of History (Saint-Petersburg State University, Russian Federation), and others.

Most of the research works published in Halychyna focused on the modern and contemporary history of Ukraine, ethnology. At the same time, the Journal highlighted important issues of Ancient history and the history of the Middle Ages. For instance, the focal point of the studies of both the Ukrainian scholars and their foreign counterparts were the problems of the Ukrainian-Polish relations during the modern period (I. Tsependa, L. Zashkilniak, M. Lytvyn, I. Iliushyn, O. Krasivskyi, V. Komar, M. Genyk), of Ukrainian-German relations (I. Monolatii, P. Siredzhuk), Russian-Hungarian relations (M. Voloshchuk), the Ukrainian-Tatar relations of the early modern period (Ferhad Turanly), Ukrainian-Romanian relations (V. Kroitor), Ukrainian-Jewish relations (M. Hon).

A special attention was given to the issues of the Ukrainian national liberation movement in the $20^{\text {th }}$ century (O. Lysenko, O. Reient, Yu. Shapoval, V. Viatrovych, I. Patryliak, D. Vedenieiev, I. Verba, V. Trofymovych, O. Pavlyshyn, H. Starodubets, and others), to the history of the Ukrainian Greek Catholic Church (V. Marchuk, I. Pylypiv, I. Andrukhiv, I. Orlevych, and others), to the issues of the Ukrainian national revival in the $19^{\text {th }}-20^{\text {th }}$ century (M. Lesiuk, I. Raikivskyi, O. Sukhyi, and others), to the activity of the political parties in Galicia in the late $19^{\text {th }}$-early $20^{\text {th }}$ century (M. Kuhutiak, O. Zhernokleyev, I. Soliar, M. Moskaliuk, B. Savchuk, S. Kobuta, and others), to ethnological and ethnographic issues (M. Kuhutiak, L. Kozholianko, M. Pankiv, P. Kostiuchok, and others), to the issues of regional history (B. Havryliv, V. Burdulaniuk, A. Korolko, P. Arsenych, and others), the archeology of Prykarpattia (V. Baran, L. Matskevyi, S. Pyvovarov, B. Tomenchuk, I. Kochkin, T. Tkachuk, and others), to the issues of modern state formation in Ukraine (V. Kafarskyi, S. Adamovych, V. Chura, and others).

Academic works presented in the context of international and national scientific conferences held at Vasyl Stefanyk Precarpathian National University were also published in Halychyna; for example, Roman Shukherych $v$ ukrainskomu natsionalno-vyzvolnomu rusi XX stolittia (Roman Shukherych in the Ukrainian National Liberation Movement of the $20^{\text {th }}$ Century) dedicated to the $100^{\text {th }}$ anniversary of his birth (the issue of the Journal came out in 2008); Stepan Bandera v ukrainskomu natsionalno-vyzvolnomu rusi XX stolittia (Stepan Bandera in the Ukrainian National Liberation Movement of the $20^{\text {th }}$ Century) dedicated to the $100^{\text {th }}$ anniversary (the issue came out in 2009); Zakhidno-Ukrainska Narodna Respublika. Do 95-richchia utvorennia (The West Ukrainian People's Republic. The 95 th Anniversary of the Republic's Formation) (the issue came out in 2014); Ukrainska povstanska armiia - fenomen vitchyznianoi i svitovoi istorii XX stolittia (The Ukrainian Insurgent Army: A Phenomenon of the 20 $0^{\text {th }}$ Century National and World History) dedicated to the $70^{\text {th }}$ anniversary of the UIA formation (the issue came out in 2013). Several issues of Halychyna were dedicated to the anniversaries of the scholars of Precarpathian National University. For example, the 
double issue 2001 was dedicated to the $80^{\text {th }}$ anniversary of a well-known Ukrainian historian, Doctor of History, Professor Oleksandr Karpenko, who had been working at the University since 1975. The issue 2012 was prepared by the colleagues and pupils of Mykola Kuhutiak, the long-term Director of the Institute of History, Political Science, and International Relations and the Journal's Chief Editor; the issue was dedicated to his $60^{\text {th }}$ anniversary. The 2013 issue of Halychyna honoured Doctor of History, Professor Volodymyr Hrabovetsky, the long-term Chairperson of the Department of the History of Ukraine; the issue was dedicated to Professor Hrabovetsky's 85 ${ }^{\text {th }}$ anniversary. The double issue 2012 contained a large section dedicated to the $350^{\text {th }}$ anniversary of Ivano-Frankivsk. The latest, $27^{\text {th }}$ issue (2015) was dedicated to the $25^{\text {th }}$ anniversary of the Department of the History of Ukraine at Vasyl Stefanyk Precarpathian National University.

Much attention is given to the works of young researchers, postgraduate students, (the Research Debut section). For instance, more than 200 articles by postgraduate and external postgraduate students, and a dozen and a half articles produced by undergraduate students in collaboration with their research supervisors were published between 1997 and 2014. In the Journal, there were published Doctoral (Candidate/Doctor of Science) Thesis Defense reports provided by the Scientific Secretaries of the Specialized Scientific Council at the Institute of History, Political Science, and International Relations I. Raikivskyi and A. Korolko (2003-2016).

Halychyna, one of the first journals of its kind in the independent Ukraine, promoted knowledge of the national and cultural traditions of Galicia - the 'small' homeland, encouraged the dissemination of the Ukrainian national idea, facilitated the development of patriotism in young people.

Objective, unbiased research on vital, yet insufficiently explored issues of regional history, objective presentation of the historical past, popularization of the Ukrainian people's cultural heritage are significant factors in spiritual development and consolidation of the modern Ukrainian Nation.

\section{REFERENCES}

[1] Довженко О.П. Сторінки щеоденника (1941-1956). К., 2004.

[Dovzhenko O.P. Storinky shchodennyka (1941-1956). K., 2004.]

[2] Слово до читачів. Галичина. Науковий $і$ культурно-просвітній краєзнавчий часопис. Івано-Франківськ, 1997.

[Slovo do chytachiv. Halychyna. Naukovyi i kulturno-prosvitnii kraieznavchyi chasopys. Ivano-Frankivsk, 1997.]

Address: Mykola Kuhutiak, Ihor Raikivskyi, Oleh Yehreshii, Vasyl Stefanyk Precarpathian National University, 57, Shevchenko Str., Ivano-Frankivsk, 76025, Ukraine.

E-mail: decanat_istor@pu.if.ua; i.raj@ukr.net; ludyna@ukr.net.

Received: 18.07.2017; revised: 22.09.2017.

Кугутяк Микола, Райківський Ігор, Егрешій Олег. “Науковий і культурно-просвітній краєзнавчий часопис Галичина": крізь призму 20-річчя видавничої діяльності. Журнал Прикарпатського університету імені Василя Стефаника, 4 (2) (2017), 134-138. 
у статті висвітлюеться двадцятирічна видавнича діяльність “Наукового і культурнопросвітнього краєзнавчого часопису Галичина", що став одним із перших українських часописів у незалежній Україні для істориків, філологів, мистецтвознавців. На сторінках “Галичини” друкувалися статті відомих вчених, причому не лише з Прикарпатського національного університету імені Василя Стефаника, а й з багатьох інших вищих навчальних закладів України. У науковому і культурнопросвітньому краєзнавчому часописі “Галичина" матеріали друкувалися в різних рубриках: археологія, історія, етнологія, політологія, історіографія, джерелознавство, документи й матеріали, культурологія, мистецтвознавство, історична біографістика та ін. Більша частина наукових статей, уміщених у часописі, висвітлювала проблеми нової і новітньої історії України, включаючи сьогодення, етнології. Особливу увагу науковці приділяли дослідженню українського національно-визвольного руху в XX ст., проблемам українського національного відродження XIX -XX ст. партійно-політичного життя в Галичині кінця XIX - початку XX ст., джерелознавства та історіографії України, історичного краєзнавства, сучасним державотворчим процесам в Україні та ін.

Ключові слова: науковий і культурно-просвітницький краєзнавчий часопис “Галичина", історія, Прикарпатський національний університет імені Василя Стефаника, видавнича діяльність. 